\title{
NUT-partisiipin variaatiosta rajakarjalaismurteissa: (n)nA-, n- ja nUn-partisiippien keskinäisestä suhteesta
}

\author{
ILIA MOSHNIKOV \\ Itä-Suomen yliopisto
}

Tiivistelmä. Karjalan kieltä puhuttiin ennen toista maailmansotaa laajalti Suomen Raja-Karjalassa. Alueen kielimuotoa nimitetään rajakarjalaismurteiksi. Nykyisin suurin osa karjalankielentaitoisista suomalaisista on rajakarjalaistaustaisia. Karjalan kielen rajakarjalaismurteet ovat olleet kontaktissa sekä suomen että venäjän kielen kanssa. Yksi seuraus kontaktista suomeen on NUT-partisiipin morfologinen variaatio, jossa alkuperäisten karjalaisten partisiippityyppien rinnalla esiintyy suomen kielestä lähtöisin olevia tyyppejä. Artikkelissa käsitellään rajakarjalaismurteissa esiintyvää suomen savolaismurteista lainattua ( $n) n A$-tunnuksista partisiippia (esim. sanonna) suhteessa alkuaan karjalaisiin $n$ - ja $n U n$-tunnuksisiin partisiippeihin (sanon, tarvinnun). Savolaisen (n)nA-tyypin ja karjalaisten $n$ - ja $n U n$-tyyppien on esitetty olevan myös historiallisessa yhteydessä toisiinsa. Tilastollisten menetelmien avulla tarkastellaan kolmen partisiippityypin esiintymistä ja keskinäistä suhdetta rajakarjalaismurteissa.

Avainsanat: NUT-partisiippi; kielen vaihtelu; kielikontakti; tilastollinen analyysi; suomi; karjala 


\section{Johdanto}

Raja-Karjala oli ennen toista maailmansotaa Suomen karjalankielinen alue, jossa puhutut karjalan kielen varieteetit, niin kutsutut rajakarjalaismurteet, kuuluivat kahteen karjalan kielen päämurteeseen: osaksi varsinaiskarjalan eteläkarjalan murteeseen, osaksi livvin- eli aunuksenkarjalaan. Etelä- ja livvinkarjalan välillä ei kuitenkaan ollut jyrkkää rajaa vaan siirtymämurteiden jatkumo. Raja-Karjalaan kuuluivat Suojärven, Salmin, Soanlahden, Impilahden, Korpiselän ja Suistamon pitäjät, ja kielellisesti myös Ilomantsin itäosat. Rajakarjalaismurteita on tutkittu aiemmin vain vähän. Toisen maailmansodan jälkeen 1944 luovutetun Raja-Karjalan väestö asutettiin muualle Suomeen. (Ks. tarkemmin esim. Turunen 1982; Leskinen 1998; Uusitupa ym. 2017: 81-82; Koivisto 2018 : $59,76$.

NUT-partisiipin variaatio rajakarjalaismurteissa on runsasta: niissä esiintyy kymmenkunta eri NUT-partisiipin morfologista tyyppiä (Moshnikov 2014; Uusitupa ym. 2017: 88-89). Partisiippivarianttien erottavana tekijänä on NUT-partisiipin morfologinen tunnus, johdin, joka liittyy verbin vartaloon. Tarkastelen tässä artikkelissa rajakarjalaismurteiden kolmea NUT-partisiippityyppiä, varsinaiskarjalalle ominaisia $n$ - ja $n U n$-tunnuksisia partisiippeja (esim. kaččo-n, näh-nyn) sekä suomen savolaismurteille ominaista $(n) n A$-tunnuksista partisiippia eli ns. essiivipartisiippia (esim. sano-nna). Tutkimusaineisto on peräisin Raja-Karjalan korpuksesta (ks. tarkemmin luku 2).

Verbien NUT-partisiipilla on keskeinen asema karjalan ja suomen verbintaivutuksessa: se esiintyy taivutusmuodoissa osana kielteistä imperfektiä sekä myönteistä ja kielteistä perfektiä ja pluskvamperfektiä (VISK, määritelmät s.v. NUT-partisiippi), esim. suomen ei sanonut, on sanonut, ei ole sanonut, oli sanonut, ei ollut sanonut. Lisäksi NUTpartisiippia käytetään suomessa ja karjalassa substantiivin määritteenä, esim. kuollut kuolluh kala.

$n$ - ja $n U n$-partisiippityypit esiintyvät laajasti vienankarjalassa, eteläkarjalassa ja myös tverinkarjalassa. Karjalan kielen toisessa päämurteessa 
livvinkarjalassa NUT-partisiipin päävariantti taas on $h$-loppuinen $n U h$-tunnuksinen tyyppi (esim. kaččo-nuh). (Bubrih 1997: kartta 161.) (n)nA-tunnuksinen essiivipartisiippi ei kuulu karjalan kielen alkuperäisiin piirteisiin, vaan se on lainautunut rajakarjalaismurteisiin suomen kielestä. Eräitä rajakarjalaismurteissa esiintyviä partisiippitunnuksia esiintyy sekä suomessa että karjalassa (esim. $n U t, n U$ ).

Ajatuksen tarkastella ( $n) n A, n$ - ja $n U n$-partisiippivarianttien keskinäistä suhdetta rajakarjalaismurteissa herätti Matti Larjavaaran artikkeli savon "supiinista" eli essiivipartisiipista. Larjavaaran mukaan savolainen essiivipartisiippi on voinut kehittyä karjalaisesta $n$-loppuisesta partisiipista (Larjavaara 1995: 135). Käsittelen tässä artikkelissa yllämainittujen partisiippityyppien esiintymistä ja keskinäistä suhdetta rajakarjalaismurteita edustavassa aineistossa. Esitän näiden kolmen tyypin alueellisen jakauman aineistossani. Lisäksi tutkin tilastollisten menetelmien avulla, missä konteksteissa kyseiset partisiippityypit esiintyvät ja minkälaista morfosyntaktista ympäristöä ne suosivat. Kvantitatiivisella tarkastelulla pyrin selvittämään, mitkä muuttujat selittävät parhaiten essiivipartisiipin kehitystä sekä lainautumista rajakarjalaismurteisiin. Tutkimusote on aineisto- ja menetelmäkeskeinen (aineistosta ja menetelmistä ks. luku 2).

Analysoin aineistoa kvantitatiivisesti kolmesta eri näkökulmasta. Ensinnäkin selvitän frekvenssilaskelmien avulla partisiippivarianttien yleisyyssuhteet ja alueellisen jakauman. Toiseksi tarkastelen ristiintaulukoinnin avulla, missä suhteessa tarkastelemani partisiippityypit ovat jokaiseen selittävään muuttujaan (joista ks. luku 2). Tilastollisen riippuvuuden osoitan khiin neliö -testin avulla. Kolmanneksi tutkin päätöspuumenetelmän avulla, millaisia tilastollisesti merkitseviä riippuvuuksia on eri muuttujien välillä samaan aikaan. Savolaislähtöisen $(n) n A$-tyypin esiintyminen tiettyjen tilastollisen tarkastelun muuttujien yhteydessä rajakarjalaismurteiden puhujilla voi kertoa siitä, minkä kontekstien kautta essiivipartisiippi on omaksuttu rajakarjalaismurteisiin. Tilastollinen riippuvuus osoittaa, ettei tyypin esiintyminen tietyssä kontekstissa ole sattumaa. 
Artikkelin rakenne on seuraava: luvussa kaksi esittelen tutkimusaineistoni, käyttämäni menetelmät ja tutkimuskysymykset. Luvussa kolme esittelen tarkasteltavat partisiippityypit ja niiden taustaa sekä aiempaa tutkimusta. Luvussa neljä ja viisi analysoin tilastollisten testien tuloksia esimerkkeineen. Lopuksi pohdin luvussa kuusi tutkimukseni tuloksia sekä käyttämieni menetelmien toimivuutta.

\section{Aineistosta ja menetelmistä}

Karjalan kielen rajakarjalaismurteita on tallennettu Suomen kielen nauhoitearkistoon (SKNA) 1960- ja 1970-luvulla. Haastateltavat informantit ovat syntyneet Raja-Karjalassa 1800-luvun lopussa tai 1900-luvun alussa ja muuttaneet sotien jälkeen muualle Suomeen, tavallisesti savolaismurteiden puhuma-alueelle. Itä-Suomen yliopistossa on litteroitu FINKA-tutkimushankkeessa vuosina 2011-2014 noin 119 tuntia rajakarjalaisnauhoitteita. Tämä litteroitu aineisto muodostaa Raja-Karjalan korpuksen, joka tällä nimellä sisältyy nyttemmin Kielipankki-kokoelmaan. Esimerkkien yhteydessä viittaan haastatteluihin pitäjän nimellä ja nauhoitearkiston mukaisella arkistosignumilla (esim. Ilomantsi 5115: 1a).

Tutkimuskohteena on kolme partisiippityyppiä, joita on käytetty kielteisen imperfektin tai liittotempuksen eli kielteisen ja myönteisen perfektin ja pluskvamperfektin osana. Aineisto sisältää 482 partisiippiesiintymää ja on peräisin kaikkiaan 26 rajakarjalaiselta informantilta, joilta kultakin on noin tunnin pituinen nauhoite. Aineisto sisältää 159 n-tyypin esiintymää (on sanon), 133 nUn-tyypin esiintymää (on nähnyn) ja 190 (n)nA-tyypin esiintymää (on sanonna) (tarkemmin luvussa 3). Tämän artikkelin aineisto muodostaa osan väitöskirjatutkimukseni (Moshnikov, tekeillä) aineistosta.

Partisiippiesiintymät on ensin poimittu korpuksesta konteksteineen ja sitten koodattu niin, että aineiston selitettävänä muuttujana on partisiippityyppi (eli morfologinen tyyppi: $-n,-n U n,-(n) n A$ ) ja selittävinä muuttujina ovat verbityyppi, verbivartalon tavumäärä, lausekontekstin 
polaarisuus, modus, tempus, vartaloisuus ja pitäjä. Verbityypillä tarkoitan tässä verbien jakoa ryhmiin morfofonologisin perustein: $A_{-}^{-,} O_{-}, U_{-}^{-}$, $e$ - ja $i$-tyyppiset verbit ovat yksivartaloisia verbejä, joiden vokaalivartalo päättyy kyseiseen vokaaliin; $V V$-tyyppi on yksivartaloinen verbi, jonka vartalo päättyy pitkään vokaaliin tai diftongiin (syödä: sÿ̈-, tuoda: tuo-). $S$ - ja $E$-tyyppiset verbit ovat kaksivartaloisia verbejä: $S=$ supistumaverbi (tarjota : tarjoa-), $E=$ kaksivartaloinen verbi, jonka vokaalivartalo on $e$-loppuinen (olla : ole-, mennä : mene-). Verbivartalon tavumäärällä tarkoitan sen vartalon tavumäärää, johon NUT-partisiipin tunnus liittyy. Polaarisuus viittaa lausekontekstin myöntö- tai kieltomuotoisuuteen. Jokainen esiintymä on myös koodattu moduksen (tapaluokan) ja tempuksen (aikamuodon) näkökulmasta. Vartaloisuudella tarkoitan verbien jakoa yksi- ja kaksivartaloisiin verbeihin. Yksivartaloisella verbillä on yksi vokaalivartalo, kaksivartaloisella verbillä on sekä vokaali- että konsonanttivartalo. Yhdessä muuttujat kuvaavat morfosyntaktista kontekstia eli ympäristöä, jossa ovat mukana sekä morfologiset (esim. verbin vartaloisuus) että syntaktiset muuttujat (esim. tempus).

Aineisto on koodattu Excel-taulukkoon ja analysoitu RStudio- ja SPSS-tilasto-ohjelmia käyttäen. SPSS-ohjelman avulla lasken aineiston frekvenssit ja teen ristiintaulukoinnit (ks. luku 4). RStudio-ohjelmalla puolestaan käsittelen aineistoa päätöspuumenetelmällä (ks. luku 5). Luokittelevalla päätöspuulla selvitän selitettävän muuttujan (partisiippityyppi) ja selittävien muuttujien keskinäistä suhdetta. Menetelmä mahdollistaa usean muuttujan huomioon ottamisen samanaikaisesti. Prosessi jakaa aineistoa selittävien tekijöiden perusteella ryhmiin niin kauan, kunnes eri ryhmien välille syntyy tilastollisesti merkitseviä eroja $(\mathrm{p}<0,05)$. Jakamisen tuloksena syntyy puukuvio, jossa aineisto on jakaantunut alaryhmiin niin, että ylimpänä puussa on koko aineisto, josta alaryhmät haarautuvat. Tilastollisesti ei-merkitsevät muuttujat jäävät automaattisesti kuvion ulkopuolelle. (Baayen 2008: 148-149; 2013: 25; Levshina 2015: 291-297; Väänänen 2016: 45.)

Esittelen tässä artikkelissa pienemmän aineiston valossa tutkimusmenetelmiäni, joita sovellan isompaan aineistoon väitöskirjassani. 
Käsittelen aineistoa kvantitatiivisia menetelmiä soveltaen ja pyrin vastaamaan seuraaviin kysymyksiin:

- Mikä on käsittelemieni partisiippivarianttien alueellinen jakauma rajakarjalaismurteissa?

- Mitkä kielelliset muuttujat vaikuttavat eri partisiippityyppien esiintymiseen?

- Miten suomalaisperäinen (n)nA-tyyppinen partisiippi eroaa muuttujien valossa kahdesta muusta tarkasteltavasta partisiippityypistä, ja minkälaista morfosyntaktista kontekstia se suosii?

Näillä menetelmillä rajakarjalaismurteiden aineistoa ei ole tarkasteltu aiemmin. Tilastollisten ohjelmien hyödyntäminen avaa uusia näkökulmia kielikontakti- ja variaationtutkimukseen, vaikka aineiston käsittely ja testien toteutus ovat melko hidas ja työläs prosessi.

\section{Tarkasteltavat NUT-partisiipin tyypit}

Partisiippien runsaasta variaatiosta rajakarjalaismurteissa on ensimmäisten joukossa raportoinut Arvid Genetz (1880: 217). Rajakarjalaismurteissa tavataan varsinaiskarjalalle ominaiset $n-, n U n$ - ja $t$-tunnuksiset NUT-partisiipin tyypit (esim. sanon, nähnyn, sanot) ja livvinkarjalalle ominainen $n U h$-loppuinen tyyppi (sanonuh) mutta myös suomen itäisille savolaismurteille ja kaakkoismurteille ominaiset $n U t,(n) n A, n U$, $n U^{x}, n t$-loppuiset partisiipit (esim. sanonut, sanonna, sanonu, sanon $\mathcal{u}^{x}$, sanont) ja lisäksi eräitä muitakin partisiippityyppejä (Koivisto 2013; Moshnikov 2014: 35, 70; Uusitupa ym. 2017: 88-89).

Taulukossa 1 on esitelty $n$-, $(n) n A$ - ja $n U n$-tyyppien jakauma rajakarjalaismurteissa. Tyyppien alueellista jakaumaa havainnollistetaan kartassa 1 siten, että ruudullinen pallo tarkoittaa $(n) n A$-tyyppiä, musta pallo $n U n$-tyyppiä ja harmaa pallo $n$-tyyppiä. Pallon koko viittaa tyypin frekvenssiin: suurempi pallo tarkoittaa suurempaa frekvenssiä.

Alueellinen frekvenssijakauma kertoo, että suomesta lainattua essiivipartisiippia esiintyy selvästi eniten Raja-Karjalan länsiosissa, missä kontaktit suomen kieleen ovat olleet runsaampia, kun taas 
TAULUкKо 1. n-, (n)nA- ja nUn-tyyppien jakauma pitäjittäin

\begin{tabular}{|l|c|r|r|r|r|r|r|r|}
\hline \multirow{2}{*}{ Tyyppi } & \multicolumn{6}{|c|}{ Pitäjä } & \multirow{2}{*}{ Yht. } \\
\cline { 2 - 8 } \multicolumn{2}{|c|}{} & $\begin{array}{c}\text { Ilo- } \\
\text { mantsi }\end{array}$ & $\begin{array}{c}\text { Impi- } \\
\text { lahti }\end{array}$ & $\begin{array}{c}\text { Korpi- } \\
\text { selkä }\end{array}$ & Salmi & $\begin{array}{c}\text { Suis- } \\
\text { tamo }\end{array}$ & $\begin{array}{c}\text { Suo- } \\
\text { järvi }\end{array}$ & \\
\hline \multirow{3}{*}{$n$} & määrä & 13 & 57 & 11 & 2 & 21 & 55 & 159 \\
\cline { 2 - 9 } & $\%$ & $8,2 \%$ & $35,8 \%$ & $6,9 \%$ & $1,3 \%$ & $13,2 \%$ & $34,6 \%$ & $100,0 \%$ \\
\hline \multirow{2}{*}{$(n) n A$} & määrä & 178 & 2 & 4 & 0 & 2 & 4 & 190 \\
\cline { 2 - 9 } & $\%$ & $93,7 \%$ & $1,1 \%$ & $2,1 \%$ & $0,0 \%$ & $1,1 \%$ & $2,1 \%$ & $100,0 \%$ \\
\hline \multirow{2}{*}{$n U n$} & määrä & 0 & 0 & 0 & 0 & 5 & 128 & 133 \\
\cline { 2 - 8 } & $\%$ & $0,0 \%$ & $0,0 \%$ & $0,0 \%$ & $0,0 \%$ & $3,8 \%$ & $96,2 \%$ & $100,0 \%$ \\
\hline \multirow{2}{*}{ Yht. } & määrä & 191 & 59 & 15 & 2 & 28 & 187 & 482 \\
\cline { 2 - 8 } & $\%$ & $39,6 \%$ & $12,2 \%$ & $3,1 \%$ & $0,4 \%$ & $5,8 \%$ & $38,8 \%$ & $100,0 \%$ \\
\hline
\end{tabular}

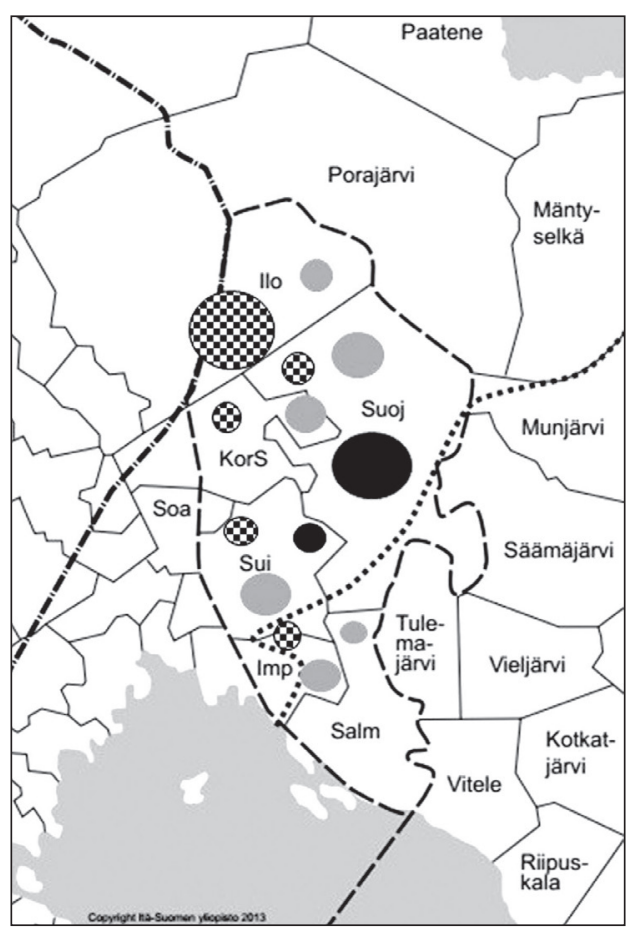

KARTTA 1. n-, (n)nA- ja

nUn-tyyppien esiintyminen rajakarjalaismurteissa (ruudullinen pallo $=(\mathrm{n}) \mathrm{nA}$, harmaa $=\mathrm{n}$, musta $=\mathrm{nUn}$ ). Isompi pallo viittaa suurempaan frekvenssiin. Kartassa näkyy nykyinen Suomen ja Venäjän valtakunnanraja, mutta myös entinen Suomen ja Neuvostoliiton raja. Mustalla pisteviivalla on esitetty Raja-Karjalan poikki kulkeva varsinaiskarjalan ja livvinkarjalan murreraja 
karjalalle ominaiset $n$ - ja $n U n$-tyyppiset partisiipit ovat yleisiä alueen itäosissa Suojärvellä ja Impilahdella. Toisaalta essiivipartisiippi on voinut edelleen vahvistaa asemiaan rajakarjalaisten kielessä toisen maailmansodan jälkeen, kun rajakarjalaiset siirrettiin suomen savolaismurteiden puhuma-alueelle. Muissa pitääaineistoissa tyyppiä esiintyy vain satunnaisesti. (n)nA-tyyppi on vahva etenkin Ilomantsin rajakarjalaisilla; esimerkiksi Karvisen tutkimuksessa (1983: 4) $n$ - tai $n U n$-tyyppiä ei esiinny Ilomantsin Melaselän rajakarjalaistaustaisilla informanteilla lainkaan.

Varsinaiskarjalassa tyypillisimpiä ovat $n$ - ja $n U n$-tyyppiset partisiipit: mies ei joutan (Ilomantsi 509: 1b), ei ollun kogo (Suojärvi 3095:1a). Muotoja esiintyy myös Tverin (en ollun, en nähnyn) ja Novgorodin kielisaarekkeiden murteissa. (Tunkelo 1939: 7; Zaikov 2000: 149.) Tunnus nun/ nyn liittyy yksivartaloisten verbien yksitavuiseen vokaalivartaloon (esim. voi-nun, tuo-nun). Kaksivartaloisilla verbeillä tunnus liittyy konsonanttivartaloon (esim. näh-nyn, varan-nun, pur-run). Tunnus $n$ puolestaan liittyy monitavuisilla yksivartaloisilla verbeillä vahvaan vokaalivartaloon (esim. kaččo-n, juotta-n, tietä-n). (Zaikov 2013: 204.) Rajakarjalaismurteiden aineistossa esiintyy myös sellaisia muotoja, joissa yksivartaloisen verbin yhteydessä esiintyy $n U n$-tyyppistä partisiippia, esimerkiksi Suojärvellä: ol' andannun, on astunnun, ei ottanun, on kazvanun.

Kaksivartaloisen verbin yhteydessä voi esiintyä myös lyhentynyt tunnus $n$ kaikissa verbityypeissä. Silloin kyseessä on todennäköisesti analoginen lyhentyminen ja mukautuminen yksivartaloisissa monitavuisissa verbeissä esiintyvään tunnukseen. $n$-tunnus on voinut kehittyä myös itsenäisesti $(-n U t>-n t>-n)$. Viimeksi mainitun kehitysketjun kautta karjalaan on kehittynyt myös $t$-tyyppinen partisiippi $(-n U t>-n t>-t$, esim. sanot, antat). Eräissä karjalan kielen alamurteissa analoginen lyhentyminen on tapahtunut kaikissa vartalotyypeissä ja lyhentynyt $n$-loppuinen NUT-partisiippi on käytössä kaikissa verbityypeissä, esimerkiksi: emmä tietän, ei huolin, ei ruven, ei kehan. (Tunkelo 1939: 8; Zaikov 2000: 148, 150; Zaikov 2005: 97-99.)

Kielteisessä imperfektissä ja liittotempuksissa käytettävä (n)nAloppuinen NUT-partisiippi on savolaislähtöinen. Se on konsonantti- 
vartaloinen essiivi, joka on määrätapauksissa voinut vielä lyhentyä haplologisesti (antanunna > antanna). (n)nA-muodot ovat vallitsevia lähes koko savolaismurteiston alueella ja puuttuvat täysin suomen kaakkoismurteista, mikä viittaa muodon savolaislähtöisyyteen. (Kettunen 1940: kartta 32; Mielikäinen 1978: 102; Larjavaara 1995: 132; Hynönen 2016: 61.)

Tunkelon mukaan varsinaiskarjalan ollun-, antan-tyyppiset NUTpartisiipit olisivat kehittyneet ollunna-, antanunna-tyypistä (1939: 13-15). Larjavaaran mukaan (1995: 135) kehitys olisi ollut toisenlainen: tyyppi antanut on ensin supistunut antanu- tai antant-asuun ja siitä edelleen antan-asuun. Essiivipartisiipin kehitys olisi silloin ollut seuraavanlainen: muinaiskarjalaisia *ollun-, ${ }^{\star}$ syönyn-, ${ }^{\star}$ tapellun-muotoja on alettu tulkita savolaismurteiden kehityksen jossain vaiheessa konsonanttivartaloisiksi ollunna-, syönynnä-, tapellunna-essiivipartisiipeiksi. Muutos olisi lähtenyt liikkeelle 1000-1300-luvulla, jolloin hämäläisten ja muinaiskarjalaisten kielikontaktit alkoivat. (Larjavaara 1995: 136-138; ks. myös Zaikov 2005: 97-98.)

\section{Ristiintaulukoinnit ja niiden tulokset}

Esittelen tässä luvussa ristiintaulukoinnin tuloksia. Käytän ristiintaulukointia kahden kategorisen muuttujan riippuvuuden tarkasteluun, eli tarkastelen selitettävän muuttujan (partisiippityyppi) ja selittävän muuttujan (muut muuttujat) keskinäistä suhdetta. Riippuvuuden tilastollinen merkitsevyys on osoitettu Pearsonin khiin neliö -testin avulla. Riippuvuuden suunnan tarkasteluun sovellan sovitettuja standardoituja jäännöksiä. Jäännökset kertovat odotettujen ja havaittujen frekvenssien eron: jäännös lasketaan niin, että odotuksenmukaisesta esiintymämäärästä vähennetään todellinen aineistossa esiintyvä frekvenssi. Tilastollisesti merkitsevä on se jäännös, joka on pienempi kuin -2 (esiintymiä on silloin odotettua vähemmän) tai suurempi kuin 2 (esiintymiä on silloin odotettua enemmän). Tilastollisen merkitsevyyden kertoo jäännöksen etäisyys nollasta: mitä kauempana nollasta arvo on, sitä merkitsevämpi 
se on. Tilastollisesti merkitseviä ovat p-arvot, jotka ovat pienempiä kuin 0,05. Testit on toteutettu SPSS-ohjelmalla. (Riazi 2016: 76; fennistiikassa soveltaneet Kunnas 2007: 96; Väänänen 2016: 46-47.) Testiä ei voi käyttää, jos yli 20 prosentissa taulukon soluista (tai ruuduista) odotuksenmukainen esiintymämäärä on 5 tai vähemmän. Tästä syystä menetelmää on myös kritisoitu (ks. esim. Mustanoja 2011: 102-103).

Taulukkoon 2 olen koonnut tiivistelmän tilastollisesti merkitsevistä muuttujista ${ }^{1}$. Kahden muuttujan tarkastelu osoittaa, että partisiippityypin ja muiden muuttujien välillä on tilastollisesti merkitsevää riippuvuutta. Tilastollista riippuvuutta pystyy testin avulla tarkastelemaan kuitenkin ainoastaan kahden muuttujan välillä ja näin taulukon muuttujat ovat enemmän suuntaa antavia, koska testissä ei oteta huomioon selittävien muuttujien yhteisvaikutusta. Partisiippityypin ja pitäjän ristiintaulukoinnin khiin neliö -testin edellytykset eivät täyttyneet yllä mainitun syyn takia, joten esitän pelkät frekvenssit ja prosenttiosuudet (ks. taulukko 1). Muiden muuttujien kohdalla testin edellytykset täyttyvät.

Tarkastelen seuraavaksi kutakin kolmea partisiippityyppiä yksityiskohtaisemmin. Testit osoittavat, että $n$-tyyppistä partisiippia esiintyy tilastollisesti merkitsevästi $A$-tyyppisen verbin yhteydessä $(59,1 \%$, $\mathrm{n}=94$, jäännös 7,2 ). Kyseisen verbityypin kanssa $n$-varianttia esiintyy odotettua enemmän (jäännös on positiivinen). $n$-varianttia esiintyy myös $U$-tyyppisen verbin yhteydessä, mutta tulos ei ole tilastollisesti merkitsevä ( $\mathrm{n}=25$, jäännös 1,1$)$. $n$-tyyppinen partisiippi suosii yksivartaloista kaksitavuista verbivartaloa, jota on käytetty kieltomuodossa. Tempuksista tilastollisesti merkitsevä on pluskvamperfekti, mutta esiintymiä on odotettua vähemmän (jäännös $-3,2$ ). Tavallinen $n$-partisiipin käyttöyhteys on siten ei tietän -tyyppinen kielteinen imperfekti. Eniten $n$-varianttia esiintyy Impilahden ja Suojärven aineistoissa (57 ja 55 esiintymää).

\footnotetext{
1 Aineisto ja testien tulokset ovat saatavilla kirjoittajalta. Yhteystiedot artikkelin lopussa.
} 
TAULUKко 2. Ristiintaulukointien tilastollisesti merkitsevät muuttujakombinaatiot sekä suurimmat pitäjäfrekvenssit

\begin{tabular}{|c|c|c|}
\hline Tyyppi & $\begin{array}{l}\text { Tilastollisesti merkitsevät muuttujat, } \\
\text { frekvenssit ja jäännöksen arvot }\end{array}$ & Esimerkit \\
\hline$n$ & $\begin{array}{l}\text { A-tyyppinen verbi }(59,1 \%, \mathrm{n}=94,7,2) \\
\text { kaksitavuinen vartalo }(78,0 \%, \mathrm{n}=124, \\
5,1) \\
\text { kielto }(62,9 \%, \mathrm{n}=100,2,6) \\
\text { pluskvamperfekti }(12,6 \%, \mathrm{n}=20,-3,2) \\
\text { yksivartaloinen }(93,1 \%, \mathrm{n}=148,7,4) \\
\text { Impilahti }(35,8 \%, \mathrm{n}=57) \\
\text { Suojärvi }(34,6 \%, \mathrm{n}=55)\end{array}$ & $\begin{array}{l}\text { mutta ku ei tietän, osotteita, } \\
\text { että mihi paikkah myö } \\
\text { jouvvuimmo ni. } \\
\text { (Impilahti 6827:1a) } \\
\text { Sidä, sid olemmo ruadan siel } \\
\text { ga. (Suojärvi } 3095: 1 \mathrm{a} \text { ) }\end{array}$ \\
\hline (n) $n A$ & $\begin{array}{l}U \text {-, } \boldsymbol{V} \boldsymbol{V} \text {-tyyppinen verbi } \\
\text { (osuudet } 17,9 \text { ja } 14,2 \%, \mathrm{n}=34 \text { ja } \mathrm{n}=27, \\
\text { jäännökset } 2,4 \text { ja } 3 \text { ) } \\
\text { kaksitavuinen }(77,9 \%, \mathrm{n}=148,5,8) \\
\text { kielto ja myöntö }(46,3 \% \text { vs. } 53,7 \%, \\
\mathrm{n}=88 \text { vs. } \mathrm{n}=102, \text { jäännös }-2,9 \text { vs. } 2,9) \\
\text { imperfekti }(37,9 \%, \mathrm{n}=72,-2,7) \\
\text { yksivartaloinen }(83,2 \%, \mathrm{n}=158,4,6) \\
\text { Ilomantsi }(93,7 \%, \mathrm{n}=178)\end{array}$ & $\begin{array}{l}\text { ja kai män'i viizi siskoo } \\
\text { oli ni kaikki mäntii hyvästi } \\
\text { naimisih ei ereyksii sattuna } \\
\text { mitää. ne mäni niì kunni- } \\
\text { jalla jotta. (Ilomantsi } \\
\text { 509:1b) } \\
\text { Tiäll_ol'i päretikku ja tiällä } \\
\text { ja, jotta se, pysy yhessä, } \\
\text { ei liikkunna. (Ilomantsi } \\
\text { 3705:1b) }\end{array}$ \\
\hline$n U n$ & $\begin{array}{l}\text { E-tyyppinen verbi }(70,7 \%, \mathrm{n}=94,14,2) \\
\text { yksitavuinen }(75,9 \%, \mathrm{n}=101,13,9) \\
\text { perfekti }(24,1 \%, \mathrm{n}=32,-2,7) \\
\text { kaksivartaloinen }(71,4 \%, \mathrm{n}=95,12,8) \\
\text { Suojärvi }(96,2 \%, \mathrm{n}=128)\end{array}$ & $\begin{array}{l}\text { a viululoi ei ollun kogo. } \\
\text { ei mis n'imes. (Suojärvi } \\
\text { 3095:1a) } \\
\text { pölyh emmo kuollun kyllä } \\
\text { elämm_i tänäpäi. (Suojärvi } \\
\text { 3082:2a) }\end{array}$ \\
\hline
\end{tabular}

(n)nA-tyyppinen partisiippi puolestaan suosii tilastollisesti merkitsevästi $U$ - ja $V V$-tyyppistä verbiä (ei sattunna, on voinna). Vaikka $A$-tyyppisestä verbistä muodostettuja partisiippeja on aineistossa enemmän (34,7 \%, $\mathrm{n}=66$ ), arvo ei ole tilastollisesti merkitsevä tässä aineistossa. Essiivipartisiippi esiintyy todennäköisimmin kaksivartaloisen kaksitavuisen verbivartalon yhteydessä imperfektissä ja myös kiellon yhteydessä, vaikka myöntömuotoja on enemmän. Tavallisia ovat siten ei sattuna, ei liikkunna -tyyppiset esiintymät. Varianttia esiintyy ylivoimaisesti eniten 
Ilomantsin aineistossa. Testin mukaan (n) $n A$ - ja $n$-varianttien morfosyntaktisilla ympäristöillä on enemmän yhtymäkohtia kuin esimerkiksi (n) $n A$ - ja $n U n$ - tai $n$ - ja $n U n$-tyyppien välillä. Vaikka $A$-tyyppisen verbin arvo ei ole tilastollisesti merkitsevä (n)nA-tyypin kohdalla, frekvenssi silti osoittaa, että tyyppi suosii laajasti $A$-tyyppistä verbiä.

$n U n$-tyyppi puolestaan suosii $E$-tyyppistä verbiä, joka on siis kaksivartaloinen verbi (esimerkiksi ei ollun, olen tullun, ol' kävellyn). Tilastollisesti merkitsevä on esiintyminen perfektissä, mutta esiintymiä on vain vähän ja jäännös on negatiivinen. Suojärven aineistossa tätä tyyppiä esiintyy ylivoimaisesti eniten.

Erikseen ristiintaulukointia tarkastellen useampi selittävä muuttuja on tilastollisesti merkitsevä. Tarkastelen seuraavaksi päätöspuumenetelmän avulla, mitkä muuttujat ovat tilastollisesti merkitseviä, kun kaikki muuttujat otetaan huomioon samanaikaisesti.

\section{Päätöspuuanalyysi}

Päätöspuu-menetelmän tulokset osoittavat, että muuttujien välillä on tilastollista riippuvuutta (katso kuvio 1). Aineiston päätöspuu sisältää 11 noodia. Ensimmäinen tilastollisesti merkitsevä muuttuja on pitäjä (noodi 1, p < 0,001), joka erottaa Ilomantsin esiintymät omaan noodinsa muusta aineistosta. Noodi 11 sisältää kaikki Ilomantsissa esiintyvät partisiipit ( $\mathrm{n}=191$ ). Aineistofrekvenssistä näkyy, että noodin muodostavat 13 n-tyypin esiintymää ja $178 n n A$-tyypin esiintymää.

Siirryn päätöspuun vasemmanpuoleisen haaran tarkasteluun. Siihen kuuluvat kaikki muut pitäjäaineistot eli Impilahden, Korpiselän, Salmin, Suistamon ja Suojärven aineistot. Tässä osa-aineistossa ensimmäisenä tilastollisesti merkitsevänä muuttujana on verbityyppi (noodi 2 , $\mathrm{p}<0,001)$. Verbityyppi jakaa aineiston kahtia $A-, e-, i-, O-, S$ - ja $U$-tyyppisestä verbistä muodostettuihin partisiippeihin ja $E-, V V$-tyyppisistä muodostettuihin. $A$-, $e-, i-, O-, S$ - ja $U$-tyyppisten sisällä tilastollisesti merkitsevänä muuttujana on pitäjä (noodi $3, \mathrm{p}<0,001$ ). Esiintymät jakaantuvat pitäjittäin seuraavasti: noodi 4 sisältää Impilahden, Korpiselän ja 


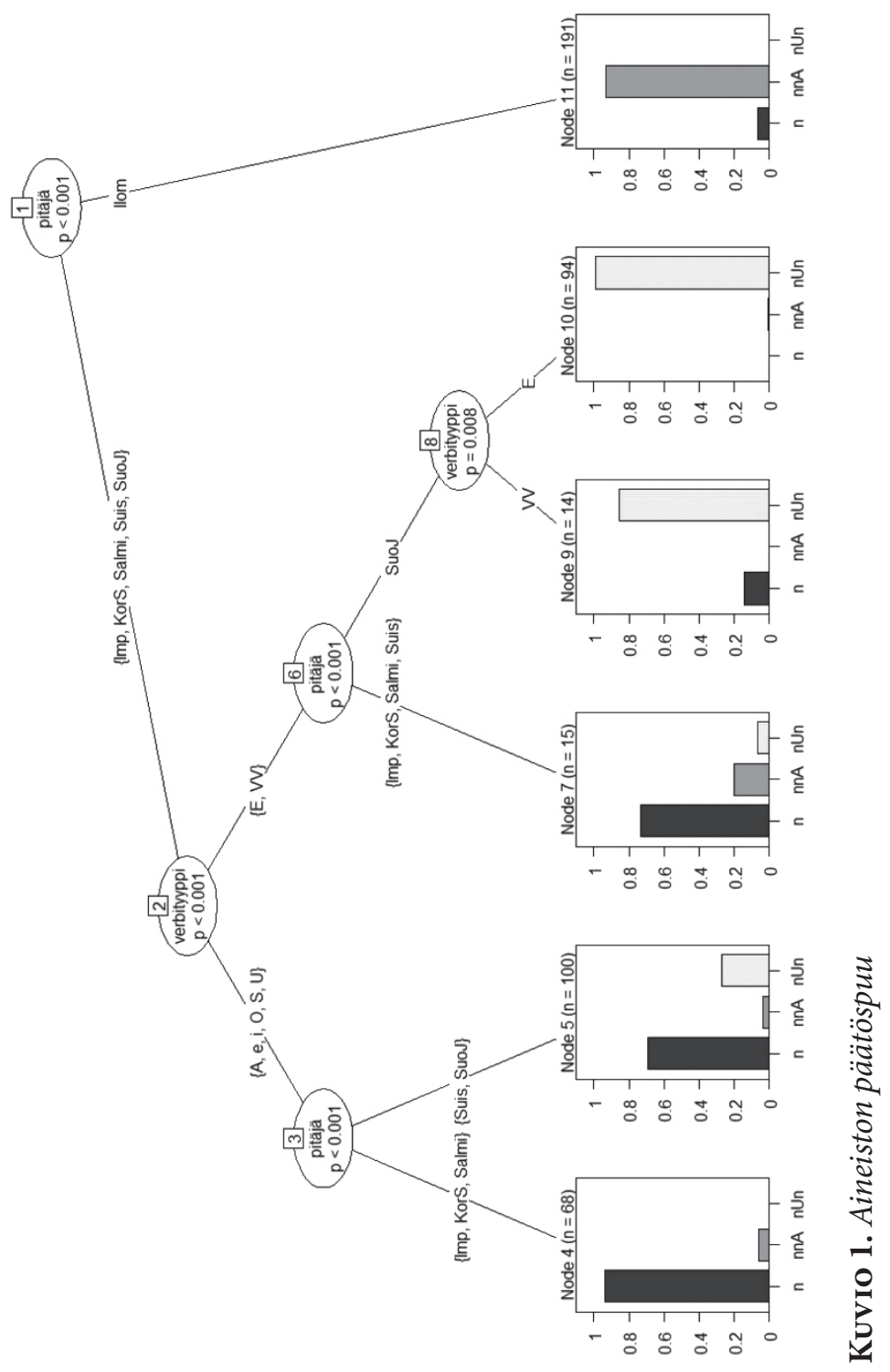


Salmin esiintymät $(\mathrm{n}=68)$, ja noodi 5 sisältää Suistamon ja Suojärven esiintymät $(\mathrm{n}=100)$. Toisen haaran muodostavat $E$ - ja $V V$-verbistä muodostetut partisiipit. $E$ - ja $V V$-tyyppisten esiintymien sisällä tilastollisesti merkitsevänä muuttujana on pitäjä (noodi $6, \mathrm{p}<0,001$ ), joka erottaa Impilahden, Korpiselän, Salmin ja Suistamon aineistot Suojärven aineistosta (noodi $7, \mathrm{n}=15$ ). Suojärven aineiston sisällä verbityyppi jakaa esiintymät $V V$-tyyppisiin ja $E$-tyyppisiin (noodi 8, p = 0,008).

Mitä kuvion 1 päätöspuu kertoo eri partisiippityyppien morfosyntaktisesta kontekstista? $n$-tyyppinen partisiippi suosii tilastollisesti merkitsevästi $A-, e-, i-, O-, S$ - ja $U$-tyyppistä verbiä ja esiintyy todennäköisimmin Suistamon tai Suojärven aineistossa, kuten myös Impilahden ja Korpiselän aineistossa. Tähän samaan noodiin neljä kuuluvat myös Salmin aineiston kaksi $n$-tyypin partisiippiesiintymää. Noodin neljä 44 ja noodin viisi 45 esiintymää ovat $A$-tyyppisestä verbistä muodostettuja NUT-partisiippeja (esim. 1 ja 2).

(1) mutta ku ei tietän, osotteita, että mihi paikkah myö jouvvuimmo ni. (Impilahti 6827:1a)

(2) Men kezän oizin ottan vie kul lehmä ol'. jotta syötän. Mikko sano olgah elägä ota. (Impilahti 6820:1b)

$n$-varianttia esiintyy myös noodeissa 7 ja 9 , mutta frekvenssit ovat paljon pienemmät. Ilomantsissa tyyppiä esiintyy 13 kertaa (viisi esiintymää $A$-typpisen verbin yhteydessä, neljä $O$-tyyppisen kanssa, kaksi $E$-tyyppisen ja kaksi $e$-tyyppisen verbin kanssa). Testin tulos tukee osittain ristiintaulukoinnin tulosta: pitäjä ja verbityyppi ovat näin vahvimmat muuttujat, ja niillä on suurin merkitys $n$-tyypin esiintymiseen.

$n U n$-tyyppistä partisiippia esiintyy puolestaan eniten noodeissa 9 ja 10, jotka kuuluvat Suojärven aineistoon. Noodin 10 muodostavat $E$-tyyppiset verbit, ja niiden yhteydessä $n U n$-tyyppistä partisiippia esiintyy eniten (esim. ei ollun, on kuollun). nUn-tyyppiä esiintyy myös $V V$-tyyppisen verbin kanssa (noodi 9), mutta näitä on vain muutama esiintymä (esim. ei voinnun, ol' tuonun). Noodi viisi sisältää 24 nUn-tyypin esiintymää, joista 16 on $A$-tyyppisestä verbistä muodostettuja (esim. 
andannun) ja muut yksittäisiä $U$-, $i$ - ja $S$-tyyppisestä verbistä muodostettuja esiintymiä (esim. astunnun, luadinnun, siepannun). Myös $n U n$ tyypin osalta päätöspuu tukee ristiintaulukoinnin tuloksia: $n U n$-tyyppiä esiintyy tilastollisesti merkitsevästi juuri Suojärven aineistossa $E$-tyyppisen verbin yhteydessä (esim. ollun, kuollun, tullun).

Essiivipartisiipin osalta päätöspuumenetelmä ei tuo paljon uutta tietoa, sillä lähes kaikki esiintymät muodostavat noodin 11 eli kuuluvat Ilomantsin aineistoon, eikä ohjelma erottele muita tilastollisesti merkitseviä muuttujia. Muissa noodeissa esiintyvät vain yksittäistapaukset (ks. myös taulukkoa 1). Muissa pitäjäaineistoissa $n n A$-tyyppiä esiintyy 2-4 tapausta, Salmista ei ole tallennettu yhtäkään esiintymää. Essiivipartisiipin osalta on tällöin hyväksyttävä ristiintaulukoinnin tulokset (ks. taulukkoa 2).

\section{Lopuksi}

Olen tarkastellut tässä artikkelissa kolmea rajakarjalaismurteiden NUTpartisiipin varianttia: niistä $n$ - ja $n U n$-tunnuksiset tyypit ovat karjalan kielen varsinaiskarjalan murteen päävariantteja ja $(n) n A$-tunnuksinen essiivipartisiippi on peräisin suomen savolaismurteista. Kaikki esiintyvät rajakarjalaismurteissa.

Aineisto osoittaa (taulukko 1 ja kartta 1), että tarkasteltavien kolmen partisiippityypin jakauma rajakarjalaispitäjissä on epäyhtenäinen, ts. varianttien alueellinen esiintyminen on erilainen. Rajakarjalaismurteiden länsiosissa ja erityisesti Ilomantsin itäosissa ( $n) n A$-tyyppiä esiintyy eniten, mutta $n U n$-tyyppiä ei lainkaan ja $n$-tyyppiä vain satunnaisesti (13 esiintymää). (n)nA-tyyppinen partisiippi on ylivoimaisesti yleisin Ilomantsin aineistossa $(93,7 \%, \mathrm{n}=178)$. Muissa pitäjäaineistoissa tätä tyyppiä puolestaan esiintyy vain satunnaisesti tai ei lainkaan (Salmin aineisto). Toisaalta $n U n$-tyyppiä esiintyy ylivoimaisesti eniten Suojärvellä $(96,2 \%, \mathrm{n}=128)^{2}$, joka sijaitsee murrealueen itäosassa. Sen

2 Tarkemmin NUT-partisiipin variaatiosta Suojärven rajakarjalaismurteessa ks. Moshnikov (tulossa). 
lisäksi on tallennettu viisi esiintymää Suistamon pitäjästä muttei muualta. Sen sijaan $n$-tyyppiä esiintyy kaikissa Raja-Karjalan pitäjissä: eniten Impilahden ja Suojärven aineistoissa ja vähiten Salmin aineistossa.

Olen tarkastellut kahta tilastollista menetelmää hyödyntäen, minkälaista morfosyntaktista ympäristöä kukin partisiippivariantti suosii. Partisiippityyppien välillä on tässä suhteessa eroja. $n$-variantti suosii kaksitavuista $A$-tyyppistä verbiä (ei ottan, ei jagan), joka esiintyy kieltokontekstissa ja todennäköisimmin Impilahden ja Suojärven aineistoissa. $n U n$-variantti puolestaan suosii yksitavuista ja kaksivartaloista E-verbiä (ei ollun, ei kuollun) ja esiintyy todennäköisimmin Suojärvellä. Näitä tuloksia tukevat sekä ristiintaulukointi (taulukko 2) että päätöspuu (kuvio 1).

Essiivipartisiipin osalta päätöspuumenetelmä ei erottele tilastollisesti merkitseviä muuttujia, joilla olisi vaikutusta variantin esiintymiseen (ks. kuvio 1). Ristiintaulukointi puolestaan osoittaa, että essiivipartisiippia esiintyy tässä aineistossa todennäköisimmin Ilomantsissa kaksitavuisen ja yksivartaloisen $U$ - tai yksitavuisen $V V$-typpisen verbin kanssa kielteisen imperfektin yhteydessä (ei sattunna, ei voinna).

On mahdollista, että essiivipartisiippi on lainautunut rajakarjalaisten kieleen juuri edellä mainittujen muotojen kautta. Tätä tukee myös $n$ - ja $n U n$-tyyppien tilastollinen jakauma, sillä ainakin $n$-tyyppinen partisiippi suosii osittain samaa kontekstia.

Essiivipartisiippi ei kuulu karjalan ominaispiirteisiin. Tyyppi on lainautunut rajakarjalaisten kieleen kielikontaktin tuloksena. Erityisen vahvasti essiivipartisiippi näyttäisi esiintyvän ilomantsilaisinformanteilla ja muilla melko harvoin tai satunnaisesti. Essiivipartisiippia suosivat selvästi ne informantit, jotka asuivat lähempänä suomalaismurteiden puhuma-aluetta ja Ilomantsin kirkonkylää, kun taas kauempana idässä asuneilla essiivipartisiippia ei esiinny. Satunnaisesiintymät muilla kuin ilomantsilaisilla informanteilla puolestaan viittaavat uudempaan, sotien jälkeiseen karjalan ja suomen väliseen kielikontaktiin, jonka tuloksena muotoja on lainautunut Suomeen muuttaneiden karjalaisten kieleen. 
Vaikka tutkimukseni lähti liikkeelle Larjavaaran (1995) hypoteesista, jonka mukaan essiivipartisiippi on kehittynyt karjalan $n$ - tai $n U n$-tyypistä, tämän aineiston valossa on vaikea osoittaa näin tapahtuneen. Essiivipartisiippia esiintyy lähinnä Ilomantsissa, muttei juurikaan muualla Raja-Karjalassa. Tilastolliset testit kuitenkin osoittavat, että (n)nA- ja $n$-tyyppiset partisiipit suosivat osittain samaa morfosyntaktista ympäristöä. Tämän perusteella kehitys $(n) n A>n$ on mahdollinen.

Raja-Karjalan toisella laidalla Suojärvellä esiintyy varsinaiskarjalan $n$ - ja $n U n$-variantteja. $n U n$-variantti on selvästi yleisempi ja sitä esiintyy sekä yksi- että kaksivartaloisen verbin yhteydessä. Tätä tyyppiä olettaisi esiintyvän enemmän myös muualla Raja-Karjalassa, koska myös muut pitäjät kokonaan tai osittain perinteisesti lasketaan varsinaiskarjalan puhuma-alueiksi. $n U n$-varianttia esiintyy kuitenkin Suojärven lisäksi ainoastaan Suistamon aineistossa.

Rajakarjalaismurteissa esiintyy muitakin partisiippityyppejä: vähintään yhdeksän suomen tai karjalan mukaista varianttia mutta myös omaperäisiä muotoja. Aineiston tarkastelu osoittaa, että informanttien väliset erot voivat olla melko suuret. Suurin variaatio on rajakarjalaismurteiden ydinpuhuma-alueella Korpiselän ja Suistamon pitäjissä, vähiten variaatiota on Salmissa. Variaatio on hyvin pitkälle idiolektisidonnaista. (Moshnikov 2014; Moshnikov, tulossa).

\section{Kiitokset}

Haluaisin kiittää erityisesti prof. Vesa Koivistoa hyödyllisistä kommenteista käsikirjoituksen viimeistelyvaiheessa. Kiitän myös tekstini kahta anonyymiä arvioijaa työpanoksestaan.

\section{Lähteet}

Baayen, Harald R. 2008. Analyzing Linguistic Data. A Practical Introduction to Statistics Using R. Cambridge: Cambridge University Press. https://doi. org/10.1017/CBO9780511801686 
Baayen, Harald R. 2013. Multivariate statistics. - Robert Podesva, Devyani Sharma (Eds.), Research Methods in Linguistics. Cambridge: Cambridge University Press, 337-372.

Bubrih, Dmitri, Aleksandr Beljakov, Aleksandra Punžina 1997. Диалектологический атлас карельского языка / Karjalan kielen murrekartasto ['Dialect atlas of Karelian']. - Leena Sarvas (Toim.), Venäjän tiedeakatemian Karjalan tiedekeskuksen kielen, kirjallisuuden ja historian instituutti. Kotimaisen kielten tutkimuskeskuksen julkaisuja 97. Helsinki: SuomalaisUgrilainen Seura.

FINKA = Suomen ja karjalan rajalla: näkökulmia lähisukukieliin ja niiden murteisiin ['On the borderline of Finnish and Karelian: Perspectives on cognate languages and dialects']. Tutkimushankkeen verkkosivut, Itä-Suomen yliopisto. https://www.uef.fi/fi/web/finka/home (18.7.2018).

Genetz, Arvid 1880. Tutkimus Venäjän Karjalan kielestä. Kielennäytteitä, sanakirja ja kielioppi ['Study on Russian Karelian']. Helsinki: Suomalaisen Kirjallisuuden Seura.

Hynönen, Emmi 2016. Suomen essiivi ['Finnish Essive']. Turun yliopiston julkaisuja. Turku: Turun yliopisto. http://urn.fi/URN:ISBN:978-951-29-6563-2

Karvinen, Erja 1983. Havaintoja Melaselän murteen savolaistumisesta ['Observations about Melaselkä dialect']. Pro gradu -tutkielma. Joensuun yliopisto.

Kettunen, Lauri 1940. Suomen murteet III A. Murrekartasto. SKS:n toimituksia 188. Helsinki: Suomalaisen Kirjallisuuden Seura.

Koivisto, Vesa 2013. Variaatiosta yhden rajakarjalaismurteen idiolekteissa ['Variation of Border Karelian idiolects']. - XL Kielitieteen päivät 2.-4.5.2013. Abstraktikirja. Tampere: Tampereen yliopisto, 174-175.

Koivisto, Vesa 2018. Border Karelian dialects: A diffuse variety of Karelian. - Marjatta Palander, Helka Riionheimo, Vesa Koivisto (Eds.), On the Border of Language and Dialect. Helsinki: Finnish Literature Society, 56-84.

Kunnas, Niina 2007. Miten muuttuu runokylien kieli: Reaaliaikatutkimus jälkitavujen A-loppuisten vokaalijonojen variaatiosta vienalaismurteissa ['The change of language in the Viena Karelian villages: A real-time study of phonological variation in Viena dialects]. Acta Universitatis Ouluensis, Humaniora B78. Oulu: Oulun yliopisto.

Larjavaara, Matti 1995. Savon - $(n) n A$-supiini ['- $(n) n A$-supine in Savo dialect']. Marjatta Palander (Toim.), Murteiden matkassa. Juhlakirja Alpo Räisäsen 60-vuotispäiväksi. Studia Carelica Humanistica 6. Joensuu: Joensuun yliopiston humanistinen tiedekunta, 132-141. 
Leskinen, Heikki 1998. Karjala ja karjalaiset kielentutkimuksen näkökulmasta ['Karelia and Karelian in the perspective of linguistic studies']. - Pekka Nevalainen, Hannes Sihvo (Toim.), Karjala. Historia, kansa, kulttuuri. Helsinki: Suomalaisen Kirjallisuuden Seura, 352-382.

Levshina, Natalia 2015. How to do Linguistics with R. Data exploration and statistical analysis. Amsterdam, Philadelphia: John Benjamins Publishing Company. https://doi.org/10.1075/z.195

Mielikäinen, Aila 1978. Aktiivin 2. partisiippi Etelä-Savon murteissa ['The past active participle in South Savo dialects]. - Virittäjä 82 (2), 101-121.

Moshnikov, Ilia 2014. NUT-partisiipin variaatio Ilomantsin rajakarjalaismurteessa ['Variations of the active past participle in the Border Karelian dialects of the Ilomantsi area]. Pro gradu -tutkielma. Itä-Suomen yliopisto. http://urn. fi/urn:nbn:fi:uef-20140271

Moshnikov, Ilia (tekeillä). NUT-partisiipin variaatio rajakarjalaismurteissa ['Variations of the active past participle in the Border Karelian dialects]. Suomen kielen alaan kuuluva väitöskirja.

Moshnikov, Ilia (tulossa). Ol' noussun sih edee, tottunuh ol' ga ei syttyny. Tapaustutkimus variaatiosta Suojärven rajakarjalaismurteessa ['Casestudy on variations in the Border Karelian Suojärvi dialect']. - Karjalankieliset identiteetit rajalla. Symposiumiin pohjautuva kokoomateos.

Mustanoja, Liisa 2011. Idiolekti ja sen muuttuminen: Reaaliaikatutkimus Tampereen puhekielestä ['Idiolect and idiolectal change a real time study of the Tampere dialect']. Tampere: Tampere University Press. http://urn.fi/ urn:isbn:978-951-44-8417-9

Raja-Karjalan korpus ['The Corpus of Border Karelia']. Kotimaisten kielten keskus. M. Palander, V. Koivisto, H. Riionheimo 2018. Raja-Karjalan korpus [puhekorpus]. Kielipankki. http://urn.fi/urn:nbn:fi:lb-2014073033

Riazi, A. Mehdi 2016. The Routledge Encyclopedia of Research Methods in Applied Linguistics: Quantitative, Qualitative, and Mixed-methods Research. London, New York: Routledge. https://doi.org/10.4324/9781315656762

Tunkelo, Eemil A. 1939. Vienalaismurteiden aktiivin II partisiipin tunnuksesta ['The past active participle in the Viena Karelian dialects']. Societas Scientiarum Fennica, vuosikirja XVII. Helsinki.

Turunen, Aimo 1982. Raja-Karjalan murteet ['Border Karelian dialects']. - YrjöPekka Mäkinen, Ilmari Lehmusvaara (Toim.), Karjala 2. Karjalan maisema ja luonto. Hämeenlinna: Arvi A. Karisto Oy, 65-89.

Uusitupa, Milla, Vesa Koivisto, Marjatta Palander 2017. Raja-Karjalan murteet ja raja-alueiden kielimuotojen nimitykset ['Border Karelian dialects and the 
terminology of Karelian borderlands' language variaties']. - Virittäjä 121 (1), 67-106.

VISK = Hakulinen, Auli, Maria Vilkuna, Riitta Korhonen, Vesa Koivisto, Tarja Riitta Heinonen, Irja Alho 2008. Ison suomen kieliopin verkkoversio ['Comprehensive grammar of Finnish']. http://scripta.kotus.fi/visk (26.2.2018)

Väänänen, Milja 2016. Subjektin ilmaiseminen yksikön ensimmäisessä persoonassa. Tutkimus suomen vanhoista murteista ['Expressing 1st person singular subject. A study of old Finnish dialects']. Annales Universitatis Turkuensis C 430. Turku: Turun yliopisto. http://urn.fi/URN: ISBN:978-951-29-6664-6

Zaikov, Petr 2000. Glagol v karel'skom jazyke ['The Karelian verb’]. Petrozavodsk: Izdatel'stvo Petrozavodskogo gosudarstvennogo universiteta.

Zaikov, Petr 2005. Karjalan kielen aktiivin II partisiippi ['The past active participle in the Karelian language']. - N. G. Zajceva (Toim.), Pribaltijsko-finskoe jazykoznanie: lingvogeografičeskie issledovanija. Petrozavodsk: Institut jazyka, literatury i istorii Karel'skogo naučnogo centra Rossijskoj Akademii Nauk, 97-107.

Zaikov, Pekka 2013. Vienankarjalan kielioppi ['The grammar of Viena Karelian']. Helsinki: Karjalan Sivistysseura ry. 


\title{
Three variants of the active past participle in Border Karelian dialects
}

\author{
ILIA MOSHNIKOV \\ University of Eastern Finland
}

This article investigates the relationship between three variants of the active past participle in Border Karelian dialects, using statistical methods.

Border Karelia is the name used for the easternmost corner of pre-war Finland, where the Karelian language was spoken. After World War II, as this region was annexed to the Soviet Union, its inhabitants were resettled in other parts of Finland; most Karelian speakers living in Finland nowadays are Border Karelian evacuees or their descendants. So far, Border Karelian dialects have not been extensively researched, but there is a Corpus of Border Karelia (RajaKarjalan korpus) based on dialect interviews conducted in the 1960s and 70s. The data for this study comes from this corpus.

Participle variation is one of the examples of morphological variation and language contact. The so-called essive participle in -nna (sano-nna 'said'), historically an essive case form of the Finnic NUT participle, is characteristic of the Finnish East Savo dialects, but it also appears in Border Karelian. According to Larjavaara's hypothesis (1995) the essive participle evolved from the older Karelian variants $n$ or $n U n$ (sano- $n \sim$ sano-n-na 'said', näh-nyn $\sim$ näh-nyn-nä 'seen'). These two other frequent participle variants in $-n$ and $-n U n$ are typical of the Karelian Proper varieties of the Karelian language. The data used in this study consists of 482 tokens of participles; of these, 190 are essive participles, 159 are of the $n$ type, and 133 of the $n U n$ type.

In this study, the correlations between morpheme variants and morphosyntactic factors as well as the territorial distribution of these variants in Border Karelian dialects were analysed. The study reveals that different variants of the past participle favor different morphosyntactic contexts. The essive participle is typical of Ilomantsi in the westernmost Border Karelian area, and it occurs especially in negative past-tense forms of verbs with the stem vowel $U$ or with a stem-final long vowel or diphthong. The $n$-type participle appears statistically 
significantly with verbs with the stem vowel $A$ in negative contexts in the Impilahti and Suojärvi areas. The $n U n$-variant favours verbs with the stem vowel $e$ and is most frequent in Suojärvi.

The occurrence of different participle variants in different contexts indicates that the essive participle was first adopted from Finnish to Karelian in a specific context. These results support Larjavaara's hypothesis and demonstrate the effect of the language contact across time. The essive participle probably superseded the older variant in the Ilomantsi area, while in the rest of Border Karelia older variants remained in use much longer.

Keywords: active past participle; variation; language contact; statistical analysis; Finnish; Karelian

\section{Ilia Moshnikov}

Itä-Suomen yliopiston karjalan tutkimuslaitos

PL 111

80101 Joensuu, Finland

ilia.moshnikov@uef.fi 